\title{
Genetic parameters for conjugated linoleic acid, selected milk fatty acids, and milk fatty acid unsaturation of Italian Holstein-Friesian cows
}

\author{
M. Mele,${ }^{\star 1}$ R. Dal Zotto, $†$ M. Cassandro,† G. Conte, ${ }^{\star}$ A. Serra, ${ }^{\star}$ A. Buccioni, $\neq$ G. Bittante, $†$ and P. Secchiari ${ }^{\star}$ \\ *Dipartimento di Agronomia e Gestione dell'Agroecosistema, University of Pisa, Via S. Michele degli Scalzi 2, 56124 Pisa, Italy \\ †Department of Animal Science, University of Padova, Viale dell'Università 16, 35020 Legnaro, Padova, Italy \\ fDipartimento di Scienze Zootecniche, University of Firenze, Via delle Cascine 5, 50100 Firenze, Italy
}

\begin{abstract}
The objective of this study was to estimate genetic parameters for conjugated linoleic acid (CLA) and other selected milk fatty acid (FA) content and for unsaturation ratios in the Italian Holstein Friesian population. Furthermore, the relationship of milk FA with milk fat and protein content was considered. One morning milk sample was collected from 990 Italian Holstein Friesian cows randomly sampled from 54 half-sib families, located in 34 commercial herds in the North-eastern part of Italy. Each sample was analyzed for milk percentages of fat and protein, and for single FA percentages (computed as FA weight as a proportion of total fat weight). Heritabilities were moderate for unsaturated FA, ranging from 0.14 for $\mathrm{C} 16: 1$ to 0.19 for C14:1. Less than 10\% of heritability was estimated for each saturated FA content. Heritability for index of desaturation, monounsaturated FA and CLA/trans-11 $18: 1$ ratio were $0.15,0.14$, and 0.15 , respectively. Standard errors of the heritability values ranged from 0.02 to 0.06 . Genetic correlations were high and negative between $\mathrm{C} 16: 0$ and $\mathrm{C} 18: 0$, as well as between C14:0 and C18:0. Genetic correlations of index of desaturation were high and negative with C14:0 and C16:0 $(-0.70$ and -0.72 , respectively), and close to zero (0.03) with C18:0. The genetic correlation of C16:0 with fat percentage was positive (0.74), implying that selection for fat percentage should result in a correlated increase of C16:0, whereas trans-11 C18:1 and cis-9, trans-11 C18:2 contents decreased with increasing fat percentage $(-0.69$ and -0.55 , respectively). Genetic correlations of fat percentage with 14:1/14 and 16:1/16 ratios were positive, whereas genetic correlations of fat percentage with 18:1/18 and CLA/trans-11 18:1 ratios were negative. These results suggest that it is possible to change the milk FA composition by genetic selection,
\end{abstract}

Received June 11, 2008.

Accepted September 12, 2008.

${ }^{1}$ Corresponding author: mmele@agr.unipi.it which offers opportunities to meet consumer demands regarding health aspects of milk and dairy products.

Key words: milk fatty acids, conjugated linoleic acid, stearoyl-CoA desaturase enzyme, genetic parameter

\section{INTRODUCTION}

Ruminant fat is an important part of the human diet in many countries, particularly bovine milk fat. Although dairy products provide only 15 to $25 \%$ of the total fat in the human diet, they provide about 25 to $35 \%$ of the total saturated fat (O'Donnell, 1993). Cow milk fat, in fact, contains a relatively low proportion of unsaturated fatty acids and a relative high proportion of saturated fatty acids, mainly C14:0 and C16:0, which have been associated with high cholesterol levels, a recognized risk factor for cardiovascular disease (Keys et al., 1965). However, the fatty acid (FA) fraction of ruminant's milk contains also several compounds of great interest for human health, such as monounsaturated FA (mainly cis-9 C18:1) and conjugated linoleic acids (CLA). Rumenic acid (cis-9, trans-11 C18:2) is the major CLA isomer in milk fat. Cis-9, trans-11 C18:2 and cis-9 C18:1 can be synthesized by the stearoylCoA desaturase enzyme (SCD) activity in the mammary gland. This enzyme plays a key role, because it introduces a double bond at the $\Delta^{9}$-position in a large spectrum of FA (Ntambi, 1999; Ntambi and Miyazaki, 2004). Its substrates can be acyl-CoA of C14:0, C16:0, C18:0, and trans-11 C18:1 (known as vaccenic acid) which are converted into C14:1 n-5, C16:1 n-7, cis-9 C18:1, and cis-9, trans-11 C18:2, respectively (Corl et al., 2001), the latter being a CLA isomer of great interest due to its antiatherogenic, anticarcinogenic and immuno-modulating properties (Pariza, 1999). More than $70 \%$ of the cis-9, trans-11 C18:2 of ruminant's milk is produced in the mammary tissue by the activity of SCD (Bauman et al., 2006). An alternative way to study the nutritional quality of milk fat, therefore, is to analyze the variations in unsaturation ratios by calculating the ratio of cis-9 unsaturated to cis-9 un- 
saturated + saturated for specific FA (Sol Morales et al., 2000; Palmquist et al., 2004).

Studies aimed at finding efficient strategies to improve the nutritional quality of milk concluded that feeding supplementation is the most efficient way to modify milk FA (Palmquist et al., 1993; Jenkins and McGuire, 2006), though recent studies have suggested that the genetic improvement of the nutritional quality of milk based on FA profile may be possible (Soyeurt et al., 2006; Soyeurt et al., 2007). Possibilities of changing milk FA composition by genetically altering proportion of FA are therefore of interest, but to apply selection programs based on performance recording and prediction of breeding values, genetic parameters for FA have to be estimated. Recently, genetic parameters for major milk FA have been estimated in Dutch and US Holstein-Friesian population (Soyeurt et al., 2007; Bobe et al., 2008; Stoop et al., 2008).

The aims of this study were to estimate genetic parameters for milk FA unsaturation, CLA and other selected milk FA, and to study the relationship of FA with milk fat and protein content in the Italian Holstein-Friesian population.

\section{MATERIALS AND METHODS}

\section{Animals}

The study was carried out on 990 Italian HolsteinFriesian cows $(\mathrm{n}=280,370$, and 340 , for the first, second, and third to seventh calving, respectively) sampled from January to July 2004 and distributed in 34 herds (29 \pm 10 cows per herd) located in the northeastern part of Italy. Cows were extracted using a data set provided by the Italian Holstein-Friesian Cattle Breeders Association (ANAFI, Cremona, Italy) to select the 54 half-sib families $(18 \pm 10$ daughters per bull) across herds. The range of DIM in which cows were sampled was 7 to 450 .

\section{Analysis of Milk Samples}

For each cow, an individual milk sample was taken at the morning milking and stored at $-20^{\circ} \mathrm{C}$. Milk fat was extracted according to Mele et al. (2007). Briefly, $2 \mathrm{~g}$ of milk was mixed with $0.4 \mathrm{~mL}$ of ammonia $25 \%, 1$ $\mathrm{mL}$ of ethyl alcohol $95 \%$, and $5 \mathrm{~mL}$ of hexane, vortexed, and centrifuged at $1,600 \times g$ for $15 \mathrm{~min}$ and $4^{\circ} \mathrm{C}$. The upper layer was collected and a second extraction with $1 \mathrm{~mL}$ of ethyl alcohol $95 \%$ and $5 \mathrm{~mL}$ of hexane was performed. A third extraction was made using $5 \mathrm{~mL}$ of hexane. The extracted fat was dried, weighed, and finally dissolved in hexane. Methyl esters of mediumand long-chain FA were prepared by the alkali catalyzed trans-methylation procedure in Christie (1982) with C19:0 methyl ester (Sigma Chemical Co., St. Louis, $\mathrm{MO})$ as the internal standard. Medium- and long-chain FA composition was determined by gas chromatography using a ThermoQuest (Milan, Italy) gas chromatograph equipped with a flame-ionization detector and a high polar fused silica capillary column (Chrompack CP-Sil 88 Varian, Middelburg, the Netherlands; $100 \mathrm{~m} \times 0.25$ $\mathrm{mm}$ i.d.; film thickness $0.20 \mu \mathrm{m}$ ). Helium was used as the carrier gas at a flow of $1 \mathrm{~mL} / \mathrm{min}$. The split ratio was 1:100. An aliquot of the sample was injected under the following gas chromatography conditions: the oven temperature was programmed at $120^{\circ} \mathrm{C}$ and held for 1 min, then increased to $180^{\circ} \mathrm{C}$ at a rate of $5^{\circ} \mathrm{C} / \mathrm{min}$, held for $18 \mathrm{~min}$, increased to $200^{\circ} \mathrm{C}$ with $2^{\circ} \mathrm{C} / \mathrm{min}$, held for 1 min, increased to $230^{\circ} \mathrm{C}$ at a rate of $2^{\circ} \mathrm{C} / \mathrm{min}$ and held for $19 \mathrm{~min}$. The injector temperature was set on $270^{\circ} \mathrm{C}$, whereas the detector temperature was set on $300^{\circ} \mathrm{C}$. Cis and trans $\mathrm{C} 18: 1$ isomers were determined on a second aliquot of the same sample at $175^{\circ} \mathrm{C}$ (isothermal step) for 65 min., using the same capillary column. Individual FA methyl esters were identified by comparing them to a standard mixture of 37 Component FAME Mix (Supelco, Bellefonte PA). The standards PUFA-2, nonconjugated C18:2 isomer mixture, individuals cis5,8,11,14,17 C20:5, cis-4,7,10,13,16,19 C22:6 (Supelco), cis-6,9,12 C18:3 and cis-9,12,15 C18:3 (Matreya Inc., Pleasant Gap, PA) were used to identify polyunsaturated FA. The identification of C18:1 isomers was based on commercial standard mixtures (Supelco) and published isomeric profiles (Wolff and Bayard, 1995). All the methods that used peak normalization and that expressed results as a relative percentage of the area of the analyzed peaks were subject to overestimation because the small peak areas were not considered. To avoid this problem, a nonadecanoic acid was used as an internal standard and all milk FA compositions were expressed as grams per 100 grams of fat. For each FA, response factors to flame ionization detector and inter- and intraassay coefficients of variation were calculated by using a reference standard butter (CRM 164, Community Bureau of Reference, Brussels, Belgium). Intraassay coefficients of variation ranged from 0.5 to $1.5 \%$, whereas interassay coefficients of variation ranged from 1.5 to $2.5 \%$.

Percentages of fat and protein were determined by infrared spectroscopy (Combi Foss 6000 FC, Foss Electric A/S, Hillerød, Denmark) at the Milk Quality Lab of Veneto Agricoltura Institute (Thiene, Italy)

\section{Ratios of Milk Fatty Acids}

The extent of FA desaturation was determined by calculating the ratio of cis-9 unsaturated to cis-9 unsat- 
urated + saturated for specific FA (Sol Morales et al., 2000; Palmquist et al., 2004). The following ratios were calculated: cis-9 C14:1 to cis-9 C14:1 + C14:0 (14:1/14); cis-9 C16:1 to cis-9 C16:1 + C16:0 (16:1/16); cis-9 C18:1 to cis-9 C18:1 + C18:0 (18:1/18); cis-9, trans-11 CLA to cis-9, trans-11 CLA + trans-11 C18:1 (CLA/ trans-11 18:1).

Moreover, a general index of desaturation (DI) was calculated (adapted from Malau-Aduli et al., 1997):

$$
\begin{gathered}
\mathrm{DI}=(\text { cis-9 C14:1 + cis-9 C16:1 + cis-9 C18:1 } \\
+ \text { cis-9, trans-11 CLA }) /(\text { cis-9 C14:1 + cis-9 C16:1 } \\
+ \text { cis-9 C18:1 + cis-9, trans-11 CLA+ C14:0 + C16:0 } \\
\text { + C18:0 + trans-11 C18:1). }
\end{gathered}
$$

\section{Statistical Analysis}

(Co)variance components for milk FA traits were estimated using the VCE package (Groeneveld, 1998) and REML animal model procedures based on multiple-trait animal models. To reduce computer memory requirements, estimation of variance components was performed in different set of 3-trait multivariate analyses; therefore, heritabilities and genetic correlations were averages of those estimates.

In preliminary analyses, the GLM procedure of SAS Institute (2004) was used to test the statistical significance of fixed effects (herd, days in milk, parity, month or season) of the linear model. Data were recorded during a single year from January to July. The effects of month of recording were not statistically significant. Thus, this effect was not included in the final linear model.

Relationships between animals were considered using a total pedigree of 7,387 animals, provided by Italian Holstein-Friesian Cattle Breeders Association (ANAFI, Cremona, Italy). The following linear model was used:

$$
\begin{aligned}
y_{i j k l m n}=\mu+ & \operatorname{Herd}_{i}+\text { Season }_{j}+\text { DIM }_{k}+\text { Parity }_{l} \\
& +\operatorname{anim}_{m}+\varepsilon_{i j k l m n}
\end{aligned}
$$

where $y_{i j k l m n}$ is a measure on a trait; $\mu$ is the general mean; $\operatorname{Herd}_{i}(i=1, \ldots, 34)$ is the fixed effect of the herd; $\operatorname{Season}_{j}(j=1, \ldots, 4)$ is the fixed effect of the season of calving; $\operatorname{DIM}_{k}(k=1, \ldots, 3)$ is the fixed effect of the class of days in milk; Parity ${ }_{l}$ is the fixed effect of the class of parity $(l=1, \ldots, 3) ; \operatorname{anim}_{m}$ is the random additive genetic effect of the animal $(m=1$, $\ldots, 7,387)$, and $\varepsilon_{i j k l m n}$ is a random residual.

Days in milk were grouped into 3 classes $(1:<100$ DIM; 2:100 to 200 DIM; 3: >200 DIM), parity was clas- sified into 3 classes for first, second, and third to seventh calving. Season effect was classified in 3-mo classes ( $1=$ spring; $2=$ summer; $3=$ autumn; $4=$ winter $)$. Least squares means of DIM effect were obtained using the GLM procedure (SAS, 2004) applying the model [1] without random animal effect. To test the differences, a multiple comparison of the mean was performed using the Bonferroni test $(P<0.05)$.

\section{RESULTS AND DISCUSSION}

Mean, standard deviation, coefficient of variation, minimum, maximum, and kurtosis values for selected FA and FA ratios are reported in Table 1. Values of kurtosis ranged from 0.35 to 6.98 . To test the normality of the distribution, the Shapiro-Wilk test was applied (SAS Institute, 2004): for all traits data may be considered as normal-distributed.

The C16:0 and cis-9 C18:1 are the major FA in milk, accounting for 24.75 and $17.39 \mathrm{~g}$ per $100 \mathrm{~g}$ of total milk lipids on average, respectively. As expected, saturated FA (the sum of C14:0, C16:0, and C18:0) was the most prominent fraction of milk FA, averaging $43 \%$ of the total milk fat, and monounsaturated FA (MUFA) averaged 20\%. Trans-11 C18:1 and cis-9, trans-11 C18:2 averaged $0.76 \%$ and $0.35 \%$ of total milk fat, respectively. These values are very close to $0.77 \%$ and $0.39 \%$ that were recently reported for a sample of 1,918 Dutch Holstein-Friesian cows (Stoop et al., 2008), for trans-11 C18:1 and cis-9, trans-11 C18:2, respectively. All selected FA showed considerable variation in milk FA composition between different cows. Cis-9, trans-11 C18:2, cis-9 C14:1, trans-11 C18:1, and cis-9 C16:1 resulted in the greatest values of coefficients of variation, accounting for $37,35,34$, and $30 \%$, respectively. Stoop et al. (2008) reported smaller values of coefficients of variation for cis-9, trans-11 C18:2 and trans-11 C18:1 (28 and 26\%, respectively), which can be explained partly by using cows with a narrower range of DIM (DIM 63-263). Previous studies reported that the content of cis-9, trans-11 C18:2 in milk is characterized by a large individual variation (up to 8-fold) that can be observed in cows fed the same diet (Bauman et al., 2001; White et al., 2001; Secchiari et al., 2003a). Therefore, an important role of the genetic background of animals has been hypothesized. Moderate coefficients of variation were found for cis-9 C14:1, C16:0, and MUFA (less than 20\%). Among the FA ratios, 14:1/14 and 16:1/16 showed the greatest coefficients of variation, accounting for $31 \%$ and $33 \%$, respectively.

\section{Lactation Stage Effect}

The least squares means of milk FA contents for different stages of lactation are reported in Table 2. The 
Table 1. Mean, SD, CV, minimum, and maximum values for selected milk fatty acids, fatty acid ratios, and milk fat and protein contents of 990 Italian Holstein-Friesian cows

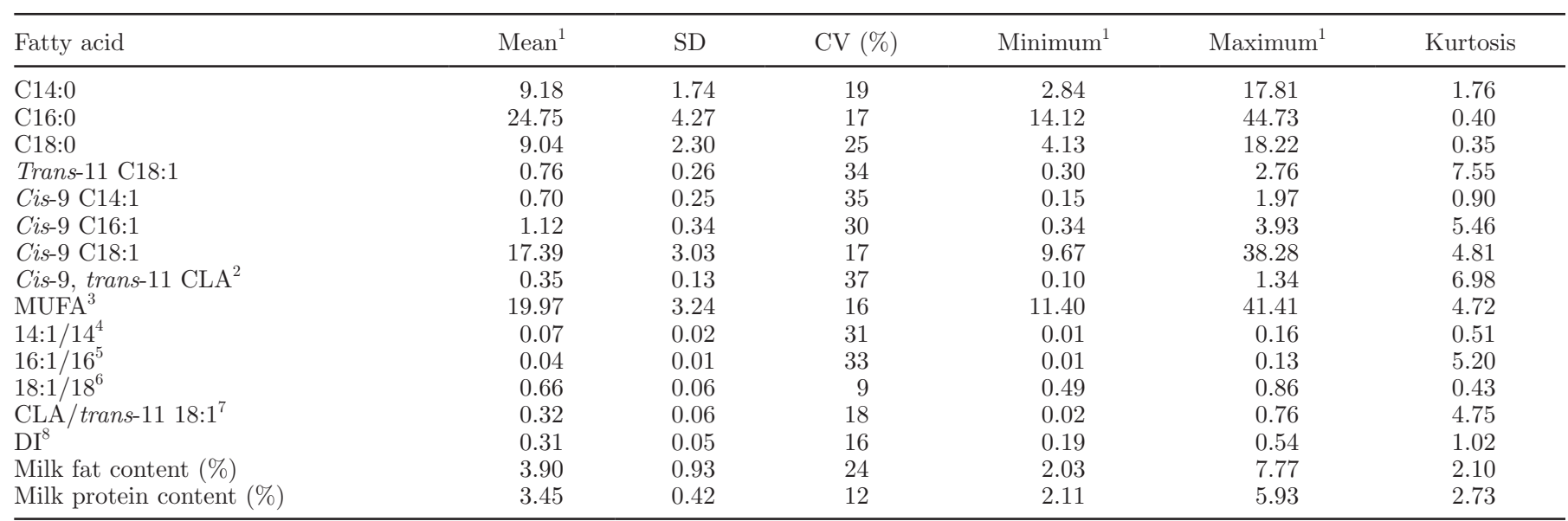

${ }^{1}$ Expressed as g of FA per $100 \mathrm{~g}$ of total lipids.

${ }^{2}$ Cis-9, trans-11 CLA $=$ cis-9, trans-11 conjugated linoleic acid.

${ }^{3} \mathrm{MUFA}=$ monounsaturated fatty acids (including cis and trans isomers of C18:1).

${ }^{4} 14: 1 / 14=$ cis-9 C14:1 / C14:0 + cis-9 C14:1.

${ }^{5} 16: 1 / 16=$ cis-9 C16:1 / C16:0 + cis-9 C16:1.

${ }^{6} 18: 1 / 18=$ cis-9 C18:1 / C18:0 + cis-9 C18:1.

${ }^{7}$ CLA/trans-11 18:1 = cis-9, trans-11 C18:2 / trans-11 C18:1 + cis-9, trans-11 C18:2.

${ }^{8} \mathrm{DI}=$ desaturation index: (cis-9 C14:1 + cis-9 C16:1 + cis-9 C18:1 + cis-9, trans-11 C18:2) / (C14:0 + cis-9 C14:1 + C16:0 + cis-9 C16:1 + cis-9C18:1 + C18:0 + trans-11 C18:1 + cis-9, trans-11 C18:2).

C14:0 and cis-9 C14:1 showed a smaller value $(P<$ 0.01 ) in the first 100 DIM compared with the rest of lactation. An opposite trend was found for C18:0 and cis-9 C18:1 with a greater value $(P<0.01)$ on the first 100 DIM, compared with the rest of the lactation. As expected, cows $<100$ DIM were more likely in a negative energy balance, therefore the lipid mobilization from the body fat reserves led to an increase in C18:0 and cis-9 C18:1 content in milk fat and to an inhibition of the mammary lipogenic enzymes that synthesize C14:0 (Palmquist et al., 1993). In early lactation preformed FA generally contribute a larger portion of the total FA, whereas the contribution from de novo FA increases as lactation progresses (Palmquist et al., 1993). C16:0 showed a greater value $(+6 \% ; P<0.01)$ in the intermediate stage of lactation (100-200 DIM) in respect to the first $(<100$ DIM) and the last ( $>200$ DIM) period of lactation. The greatest value of cis-9, trans-11 C18:2 was found in milk from cows over 200 DIM, confirming that the stage of lactation significantly affects cis-9, trans-11 C18:2 content of milk. Similar results were found in a previous study which considered variation of milk FA composition in Italian Holstein cows during a whole lactation, using repeated milk samples (Secchiari et al., 2003b). According to Kay et al. (2005), during the initial phase of lactation, values of 14:1/14 and CLA/trans-11 18:1 ratios tended to be smaller than in the rest of lactation, probably due to some inhibitory effects of preformed FA on SCD expression or activity (Bernard et al., 2006).

\section{Heritabilities of FA and Desaturation Ratios}

Heritabilities and genetic correlation for individual FA are shown in Table 3 . Low heritability values were estimated for all saturated FA analyzed: C14:0, C16:0 and $\mathrm{C} 18: 0$ showed values of $0.07,0.03$ and 0.08 , respectively. On the contrary, moderate heritability values were estimated for unsaturated FA, ranging from 0.12 for trans-11 C18:1 to 0.19 for cis-9 C14:1. Heritabilities for total MUFA, cis-9 C18:1, and cis-9 C16:1 contents were $0.14,0.17$, and 0.14 , respectively. Stoop et al. (2008), using only first lactation cows between 63 and 263 DIM, estimated greater heritabilities for saturated FA than for unsaturated FA, and constantly greater values for all FA. A greater homogeneity on environmental effects in the study of Stoop et al. (2008) can be the main reason of this difference between the results from Dutch dairy cow population and our study. Bobe et al. (2008) reported lesser values of heritabilities for individual FA content in milk from a US Holstein cow population. This study was based on repeated milk samples taken from a limited number of cows (233 cows), in a single herd with a relationship matrix based on 2 generations, which led to larger standard errors of genetic estimates. Soyeurt et al. (2007) reported a value of hereditabil- 
Table 2. Least squares means of selected milk fatty acid content ( $\mathrm{g} / 100 \mathrm{~g}$ of total lipids) and fatty acid ratios for different days in milk intervals (DIM)

\begin{tabular}{|c|c|c|c|c|c|c|}
\hline \multirow[b]{2}{*}{ Fatty acid } & \multicolumn{2}{|c|}{ DIM $<100(\mathrm{n}=170)$} & \multicolumn{2}{|c|}{ DIM 100-200 $(\mathrm{n}=520)$} & \multicolumn{2}{|c|}{ DIM $>200(\mathrm{n}=292)$} \\
\hline & Mean & $\mathrm{SE}$ & Mean & $\mathrm{SE}$ & Mean & $\mathrm{SE}$ \\
\hline C14:0 & $8.44^{\mathrm{B}}$ & 0.13 & $9.48^{\mathrm{A}}$ & 0.10 & $9.29^{\mathrm{A}}$ & 0.07 \\
\hline C16:0 & $23.99^{\mathrm{B}}$ & 0.31 & $25.75^{\mathrm{A}}$ & 0.25 & $24.72^{\mathrm{B}}$ & 0.17 \\
\hline C18:0 & $9.66^{\mathrm{A}}$ & 0.18 & $8.92^{\mathrm{B}}$ & 0.144 & $8.86^{\mathrm{B}}$ & 0.10 \\
\hline trans-11 C18:1 & $0.81^{\mathrm{a}}$ & 0.02 & $0.75^{\mathrm{b}}$ & 0.02 & $0.79^{\mathrm{a}}$ & 0.01 \\
\hline Cis-9 C14:1 & $0.56^{\mathrm{C}}$ & 0.02 & $0.68^{\mathrm{B}}$ & 0.02 & $0.77^{\mathrm{A}}$ & 0.01 \\
\hline Cis-9 C16:1 & $1.17^{\mathrm{A}}$ & 0.03 & $1.13^{\mathrm{A}}$ & 0.03 & $1.18^{\mathrm{A}}$ & 0.02 \\
\hline Cis-9 C18:1 & $18.77^{\mathrm{A}}$ & 0.26 & $16.79^{\mathrm{C}}$ & 0.21 & $17.77^{\mathrm{B}}$ & 0.14 \\
\hline Cis-9, trans-11 $\mathrm{CLA}^{1}$ & $0.33^{\mathrm{B}}$ & 0.01 & $0.34^{\mathrm{B}}$ & 0.01 & $0.39^{\mathrm{A}}$ & 0.01 \\
\hline MUFA $^{2}$ & $21.32^{\mathrm{A}}$ & 0.27 & $19.36^{\mathrm{C}}$ & 0.22 & $20.52^{\mathrm{B}}$ & 0.15 \\
\hline $14: 1 / 14^{3}$ & $0.064^{\mathrm{B}}$ & 0.002 & $0.068^{\mathrm{B}}$ & 0.002 & $0.077^{\mathrm{A}}$ & 0.001 \\
\hline $16: 1 / 16^{4}$ & $0.048^{\mathrm{A}}$ & 0.001 & $0.043^{\mathrm{B}}$ & 0.001 & $0.046^{\mathrm{A}}$ & 0.001 \\
\hline $18: 1 / 18^{5}$ & $0.659^{\mathrm{AB}}$ & 0.004 & $0.655^{\mathrm{B}}$ & 0.004 & $0.669^{\mathrm{A}}$ & 0.002 \\
\hline CLA/trans-11 18: $1^{6}$ & $0.288^{\mathrm{C}}$ & 0.005 & $0.313^{\mathrm{B}}$ & 0.004 & $0.331^{\mathrm{A}}$ & 0.003 \\
\hline $\mathrm{DI}^{7}$ & $0.328^{\mathrm{A}}$ & 0.004 & $0.298^{\mathrm{B}}$ & 0.003 & $0.318^{\mathrm{A}}$ & 0.002 \\
\hline
\end{tabular}

${ }_{\mathrm{A}, \mathrm{B}, \mathrm{C}}$ Means within rows with different superscripts differ $(P<0.01)$ according to the Bonferroni test.

${ }^{\mathrm{a}, \mathrm{b}, \mathrm{c}}$ Means within rows with different superscripts differ $(P<0.05)$ according to the Bonferroni test.

${ }^{1}$ Cis-9, trans-11 CLA $=$ cis-9, trans-11 conjugated linoleic acid.

${ }^{2}$ MUFA $=$ monounsaturated fatty acids (including cis and trans isomers of C18:1).

${ }^{3} 14: 1 / 14=$ cis-9 C14:1 / C14:0 + cis-9 C14:1.

${ }^{4} 16: 1 / 16=$ cis-9 $\mathrm{C} 16: 1 / \mathrm{C} 16: 0+$ cis-9 $\mathrm{C} 16: 1$.

${ }^{5} 18: 1 / 18=$ cis-9 C18:1 / C18:0 + cis-9 C18:1.

${ }^{6} \mathrm{CLA} /$ trans-11 18:1 = cis-9, trans-11 C18:2 / trans-11 C18:1 + cis-9, trans-11 C18:2.

${ }^{7} \mathrm{DI}=$ desaturation index: (cis-9 C14:1 + cis-9 C16:1 + cis-9 C18:1 + cis-9, trans-11 C18:2) / (C14:0 + cis-9 C14:1 + C16:0 + cis-9 C16:1 + cis-9 C18:1 + C18:0 + trans-11 C18:1 + cis-9, trans-11 C18:2).

ity for cis-9 C18:1 close to that found in the present study ( 0.15 vs. 0.17 , respectively), but greater values of hereditability for C14:0, C16:0, and C18:0. Unlike the present study, Soyeurt et al. (2007) estimated milk FA composition by mid-infrared spectrometry. The error variance of a trait may vary according to the analytical methodology used to measure it. As a consequence, differences for values of FA heritabilities between the present study and those of Soyeurt et al. (2007) may depend to the analytical methodology used. Edwards et al. (1973) cited by Bobe et al. (2008) obtained heritability estimates between $0.64(\mathrm{C} 12: 0)$ and 0.95 (C18:0) in an Ayrshire twin cow study in the United Kingdom, but, as highlighted by Bobe et al. (2008), those results were subject to overestimation because of the study design. Karijord et al. (1982) reported greater heritability estimates for C14:1 than for C14:0 (0.26 vs. 0.07) but did not observe similar trends for C16:1 (0.12) vs. C16:0 (0.15) and C18:1 (0.06) vs. C18:0 (0.15), whereas Renner and Kosmack (1974a) reported small heritabilities for unsaturated C18 content in milk fat and moderate heritabilities for saturated FA.

Heritabilities for DI, 14:1/14, 16:1/16, 18:1/18, and CLA/trans-11 18:1 were $0.15,0.27,0.12,0.13$, and 0.15 , respectively. Standard errors of the heritabilities were between 0.02 and 0.06 . In this case, the heritability values were less than those recently reported by Schen- nink et al. (2008), but similar to those reported by Royal and Garnsworthy (2005) for C14 and C18 ratios (0.30 and 0.19 , respectively). In the present study, the 14:1/C14 ratio showed the greatest value of heritability, confirming what had been reported by Schennink et al., (2008) and Royal and Garnsworthy (2005). The 14:1/14 ratio has been suggested as the best indicator for the SCD activity (Corl et al. 2001; Lock and Garnsworthy, 2003): C14:0 in milk fat derives almost exclusively from de novo synthesis in the mammary gland and, therefore, almost all the cis-9 C14:1 is likely to be synthesized by SCD (Bernard et al., 2006). Thus, cis-9 C14:1 is expected to be under stronger genetic control than the other FA considered in this study. Because C14:0 is also synthesized de novo in the mammary gland via fatty acid synthase, a greater value of heritability was expected for this FA. In this study, a very low value of heritability (0.07) was found, similar to that reported by Bobe et al. (2008) for US Holstein cows (close to zero), but much less than that reported by Stoop et al. (2008) for Dutch Holstein cows (0.49).

The heritability value of cis-9, trans-11 C18:2 was less than that reported by Stoop et al.(2008) (0.12 vs. 0.21). Because cis-9, trans-11 C18:2 is a recognized bioactive food component of milk fat, the existence of genetic variability of this FA could be used to improve the nutritional properties of milk fat by selective breeding. 
Table 3. Estimates of heritabilities (diagonal), genetic correlations (above diagonal) for selected milk fatty acids and fatty acid ratios $( \pm \mathrm{SE})$

\begin{tabular}{|c|c|c|c|c|c|c|c|c|c|c|c|c|c|c|}
\hline Fatty acid & C14:0 & C16:0 & C18:0 & $\begin{array}{c}\text { Trans-11 } \\
\text { C18:1 }\end{array}$ & Cis-9 C14:1 & $\begin{array}{cc} & C i s-9 \\
1 & C 16: 1\end{array}$ & Cis-9 C18:1 & $\begin{array}{c}\text { Cis-9, } \\
\text { trans-11 } \\
\text { CLA }\end{array}$ & MUFA & $14: 1 / 14$ & $16: 1 / 16$ & 18:1/18 & $\begin{array}{c}\text { CLA/ } \\
\text { trans-11 } \\
\text { C18:1 }\end{array}$ & DI \\
\hline C14:0 & $\begin{array}{r}0.07 \pm \\
0.03\end{array}$ & $\begin{array}{r}0.03 \pm \\
0.23\end{array}$ & $\begin{array}{r}0.09 \pm \\
0.37\end{array}$ & $\begin{array}{r}0.05 \pm \\
0.25\end{array}$ & $\begin{array}{r}-0.20 \pm \\
0.24\end{array}$ & $\begin{array}{r}-0.40 \pm \\
0.09\end{array}$ & $\begin{array}{r}-0.86 \pm \\
0.15\end{array}$ & $\begin{array}{r}-0.71 \pm \\
0.11\end{array}$ & $\begin{array}{r}-0.84 \pm \\
0.10\end{array}$ & $\begin{array}{r}-0.67 \pm \\
0.13\end{array}$ & $\begin{array}{r}-0.25 \pm \\
0.25\end{array}$ & $\begin{array}{r}-0.76 \pm \\
0.11\end{array}$ & $\begin{array}{r}-0.68 \pm \\
0.12\end{array}$ & $\begin{array}{r}-0.70 \pm \\
0.09\end{array}$ \\
\hline C16:0 & & $\begin{array}{c}0.03 \pm \\
0.02\end{array}$ & $\begin{array}{r}-0.84 \pm \\
0.34\end{array}$ & $\begin{array}{r}-0.96 \pm \\
0.20\end{array}$ & $\begin{array}{r}0.54 \pm \\
0.30\end{array}$ & $\begin{array}{r}0.50 \pm \\
0.10\end{array}$ & $\begin{array}{r}-0.92 \pm \\
0.06\end{array}$ & $\begin{array}{r}-0.41 \pm \\
0.25\end{array}$ & $\begin{array}{r}-0.89 \pm \\
0.12\end{array}$ & $\begin{array}{r}0.47 \pm \\
0.23\end{array}$ & $\begin{array}{r}0.22 \pm \\
0.42\end{array}$ & $\begin{array}{r}-0.97 \pm \\
0.87\end{array}$ & $\begin{array}{c}-0.98 \pm \\
0.12\end{array}$ & $\begin{array}{r}-0.72 \pm \\
0.15\end{array}$ \\
\hline C18:0 & & & $\begin{array}{r}0.08 \pm \\
0.04\end{array}$ & $\begin{array}{r}-0.91 \pm \\
0.30\end{array}$ & $\begin{array}{r}-0.58 \pm \\
0.22\end{array}$ & $\begin{array}{r}-0.62 \pm \\
0.18\end{array}$ & $\begin{array}{r}0.34 \pm \\
0.16\end{array}$ & $\begin{array}{r}-0.80 \pm \\
0.10\end{array}$ & $\begin{array}{r}0.06 \pm \\
0.25\end{array}$ & $\begin{array}{r}-0.48 \pm \\
0.17\end{array}$ & $\begin{array}{r}-0.42 \pm \\
0.22\end{array}$ & $\begin{array}{r}-0.60 \pm \\
0.17\end{array}$ & $\begin{array}{r}-0.61 \pm \\
0.17\end{array}$ & $\begin{array}{r}0.03 \pm \\
0.18\end{array}$ \\
\hline $\begin{array}{l}\text { Trans-11 } \\
\text { C18:1 }\end{array}$ & & & & $\begin{array}{r}0.12 \pm \\
0.04\end{array}$ & $\begin{array}{r}0.27 \pm \\
0.18\end{array}$ & $\begin{array}{r}-0.46 \pm \\
0.23\end{array}$ & $\begin{array}{r}-0.30 \pm \\
0.18\end{array}$ & $\begin{array}{r}0.48 \pm \\
0.17\end{array}$ & $\begin{array}{r}-0.24 \pm \\
0.12\end{array}$ & $\begin{array}{r}0.27 \pm \\
0.17\end{array}$ & $\begin{array}{r}-0.29 \pm \\
0.20\end{array}$ & $\begin{array}{r}0.37 \pm \\
0.31\end{array}$ & $\begin{array}{r}0.08 \pm \\
0.23\end{array}$ & $\begin{array}{r}0.03 \pm \\
0.22\end{array}$ \\
\hline Cis-9 C14:1 & & & & & $\begin{array}{r}0.19 \pm \\
0.05\end{array}$ & $\begin{array}{r}-0.03 \pm \\
0.24\end{array}$ & $\begin{array}{r}-0.55 \pm \\
0.16\end{array}$ & $\begin{array}{r}0.37 \pm \\
0.15\end{array}$ & $\begin{array}{r}-0.36 \pm \\
0.15\end{array}$ & $\begin{array}{r}0.95 \pm \\
0.03\end{array}$ & $\begin{array}{r}-0.06 \pm \\
0.27\end{array}$ & $\begin{array}{r}-0.14 \pm \\
0.21\end{array}$ & $\begin{array}{r}0.06 \pm \\
0.21\end{array}$ & $\begin{array}{r}0.30 \pm \\
0.19\end{array}$ \\
\hline Cis-9 C16:1 & & & & & & $\begin{array}{r}0.14 \pm \\
0.05\end{array}$ & $\begin{array}{r}-0.11 \pm \\
0.16\end{array}$ & $\begin{array}{r}0.34 \pm \\
0.17\end{array}$ & $\begin{array}{r}-0.05 \pm \\
0.18\end{array}$ & $\begin{array}{r}0.14 \pm \\
0.21\end{array}$ & $\begin{array}{r}0.98 \pm \\
0.03\end{array}$ & $\begin{array}{c}0.34 \pm \\
0.21\end{array}$ & $\begin{array}{r}0.52 \pm \\
0.17\end{array}$ & $\begin{array}{r}0.08 \pm \\
0.12\end{array}$ \\
\hline Cis-9 C18:1 & & & & & & & $\begin{array}{r}0.17 \pm \\
0.04\end{array}$ & $\begin{array}{r}0.28 \pm \\
0.19\end{array}$ & $\begin{array}{r}0.99 \pm \\
0.01\end{array}$ & $\begin{array}{r}-0.23 \pm \\
0.15\end{array}$ & $\begin{array}{r}0.20 \pm \\
0.20\end{array}$ & $\begin{array}{r}0.68 \pm \\
0.14\end{array}$ & $\begin{array}{r}0.57 \pm \\
0.19\end{array}$ & $\begin{array}{r}0.99 \pm \\
0.01\end{array}$ \\
\hline $\begin{array}{l}\text { Cis-9, trans- } \\
11 \text { CLA }^{1}\end{array}$ & & & & & & & & $\begin{array}{r}0.12 \pm \\
0.03\end{array}$ & $\begin{array}{r}0.29 \pm \\
0.17\end{array}$ & $\begin{array}{r}0.56 \pm \\
0.12\end{array}$ & $\begin{array}{r}0.34 \pm \\
0.08\end{array}$ & $\begin{array}{r}0.99 \pm \\
0.01\end{array}$ & $\begin{array}{r}0.94 \pm \\
0.04\end{array}$ & $\begin{array}{r}0.69 \pm \\
0.13\end{array}$ \\
\hline $\mathrm{MUFA}^{2}$ & & & & & & & & & $\begin{array}{c}0.14 \pm \\
0.04\end{array}$ & $\begin{array}{r}-0.03 \pm \\
0.19\end{array}$ & $\begin{array}{c}0.31 \pm \\
0.18\end{array}$ & $\begin{array}{r}0.78 \pm \\
0.14\end{array}$ & $\begin{array}{r}0.58 \pm \\
0.15\end{array}$ & $\begin{array}{r}0.99 \pm \\
0.01\end{array}$ \\
\hline $14: 1 / 14^{3}$ & & & & & & & & & & $\begin{array}{r}0.27 \pm \\
0.06\end{array}$ & $\begin{array}{r}0.15 \pm \\
0.20\end{array}$ & $\begin{array}{r}0.07 \pm \\
0.17\end{array}$ & $\begin{array}{r}0.24 \pm \\
0.17\end{array}$ & $\begin{array}{r}0.01 \pm \\
0.15\end{array}$ \\
\hline $16: 1 / 16^{4}$ & & & & & & & & & & & $\begin{array}{c}0.12 \pm \\
0.04\end{array}$ & $\begin{array}{r}0.45 \pm \\
0.15\end{array}$ & $\begin{array}{r}0.54 \pm \\
0.10\end{array}$ & $\begin{array}{r}0.20 \pm \\
0.15\end{array}$ \\
\hline $18: 1 / 18^{5}$ & & & & & & & & & & & & $\begin{array}{r}0.13 \pm \\
0.04\end{array}$ & $\begin{array}{c}0.99 \pm \\
0.06\end{array}$ & $\begin{array}{c}0.80 \pm \\
0.10\end{array}$ \\
\hline $\begin{array}{l}\text { CLA/trans-11 } \\
\text { C18: } 1^{6} \\
\text { DI }^{7}\end{array}$ & & & & & & & & & & & & & $\begin{array}{r}0.15 \pm \\
0.04\end{array}$ & $\begin{array}{c}0.83 \pm \\
0.14 \\
0.15 \pm \\
0.04\end{array}$ \\
\hline
\end{tabular}




\section{Genetic Correlations of FA and Desaturation Ratios}

Fatty acids C14:0 and C16:0 had strong negative genetic correlations with total MUFA and cis-9 C18:1, as did C16:0 with C18:0 (Table 3). Our results are consistent with those reported by Karijord et al. (1982). Similarly, Stoop et al. (2008) reported a negative genetic correlation $(-0.62)$ between $\mathrm{C} 14-16$ and unsaturated C18 FA. Soyeurt et al. (2007) reported a very similar genetic correlation pattern among C14:0 and MUFA (-0.84), C16:0 (close to zero) and C18:0 (0.10), whereas the genetic correlation values among cis-9 C18:1 and C14:0, C16:0 and C18:0 were less than those found in the present study. Nevertheless, C18:1 in Soyeurt et al. (2007) and cis-9 C18:1 in the present study are not the same trait. The former refers to all cis and trans isomers of C18:1, but the latter is a single isomer.

As expected, each product of the SCD enzyme was highly and positively correlated with its own specific product/substrate ratio (Table 3). Genetic correlations of DI were high and negative with C14:0 and C16:0 ( -0.70 and -0.72 , respectively), high and positive with $\mathrm{C} 18: 1$ and 18:1/18 (0.99 and 0.80 , respectively) and close to zero with C18:0 and 14:1/14 (0.03 and 0.01 , respectively). This pattern of correlation can be explained partly by the different weight of each product/substrate ratio on DI. The weight of 18:1/18 ratio on DI is much greater than that of $14: 1 / 14$ ratio, as a consequence of the greater content of C18:1 and C18:0 in milk fat. The high negative genetic correlation among saturated FA, DI, and MUFA confirmed that cows with a reduced SCD activity tended to produce milk with lesser MUFA content and with greater preformed FA (Kay et al., 2005). The values of genetic correlation between 14:1/14 and other FA ratios ranged from very low $(0.07$, with $18: 1 / 18$ ratio) to moderate (0.24, with CLA/trans-11 18:1 ratio). Schennink et al. (2008) reported that correction for SCD polymorphism, by adding the SCD genotype to the model as fixed effect, results in a greater genetic correlation among FA ratios, concluding that the correlation due to the SCD A293V polymorphism is negative for unsaturation indices, whereas the correlation due to other genetic effects is positive.

Cis-9, trans-11 C18:2 content was highly and positively correlated with 18:1/18 (0.99) and negatively correlated with C14:0 and C16:0 (Table 3). The values of genetic correlation among cis-9, trans-11 C18:2 and C14:0 and C16:0 were close to -0.60 as reported by Stoop et al. (2008). Thus, genetic selection for increasing cis-9, trans-11 C18:2 content in milk should lead to a dual nutritional improvement of milk fat: to enhance the content of bioactive FA content (cis-9 C18:1 and cis-9, trans-11 C18:2) and to decrease the content of pro-thrombotic and atherogenic FA (C14:0 and C16:0). The negative genetic correlations between trans-11 C18:1 and C18:0 could be due to genetic differences in rate of feed intake and in the rumen passage rate of feed. Actually, feed intake in cattle is moderately heritable, and animals of high genetic merit for milk have been demonstrated to have greater intakes, and use more of their body reserves in early lactation than those of low merit (Korver, 1988). High levels of feed intake and of rumen passage affect the biohydrogenation rate of dietary lipids and, consequently, the amount of C18:0 and trans-11 C18:1 accumulation in the rumen. Because C18:0 in the rumen originates mainly from hydrogenation of trans-11 C18:1 (Harfoot and Hazlewood, 1988), the greater the passage rate of feeds, the greater is the amount of trans-11 C18:1 escaping from the rumen, and the low is the amount of C18:0.

\section{Genetic Correlations of FA with Milk Fat and Protein Contents}

Genetic correlations of individual FA and milk fat and protein contents are shown in Table 4 . Fat percentage showed a positive correlation with C16:0 (0.74), and negative correlations with C14:0 (-0.40) and trans-11 C18:1, cis-9, trans-11 C18:2, and CLA/trans-11 18:1 ratio $(-0.69,-0.55$, and -0.52 , respectively). The positive correlation between $\mathrm{C} 16: 0$ and milk fat content could be due the important role of this FA for the synthesis of triacylglycerol in the mammary gland (Hansen and Knudsen, 1987). Initiation of acylation of the $s n-1$ position is a prerequisite for triacylglycerol synthesis, and C16:0 is the most preferred substrate for the initial acylation of $1-\alpha$ glycerolphosphate by acyltranferase to form sn-1 lysophosphatidic acid (Kinsella and Gross, 1973). As demonstrated by Kinsella and Gross (1973), C14:0, C18:0, and C18:1 coenzyme-A were rapidly acylated when C16:0 sn-glycero-3-phosphate was used as substrate, but were poorly acylated without the latter, indicating that these FA are taken up mostly in the second step of triacylglycerol synthesis.

In conclusion, the genetic correlation pattern suggests that increasing the fat percentage results in an increase in $\mathrm{C} 16: 0$ and a reduction of trans-11 C18:1, cis-9, trans-11 C18:2, CLA/trans-11 18:1 ratio and, to a lesser extent, C14:0. These conclusions are consistent with genetic correlation patterns reported by Stoop et al. (2008), Karijord et al. (1982), and Renner and Kosmack (1974b).

Kay et al. (2005) demonstrated that cows selected for high milk yield tended to produce milk with a greater content of C16:0 and a lesser content of MUFA. Similar changes in milk FA composition were reported for cows 
Table 4. Genetic correlations between fat and protein contents with selected milk fatty acids and fatty acid ratios



selected for differing genetic merit for milk production by Bobe et al. (2007) for the first of month of lactation, but not for the whole lactation, which suggests changes in genetic correlations across the lactation.

According to Schennink et al. (2008), genetic correlations of fat percentage with 14:1/14 and 16:1/16 ratios were positive, whereas genetic correlations of fat percentage with 18:1/18 and CLA/trans-11 18:1 ratios were negative. Protein percentage reflects the similar sign and values for the genetic correlations with FA as reported by fat percentage. The reason for these results may be the high genetic correlation between fat and protein contents (0.74, data not shown).

The cis-9 C16:1 showed the same sign for fat and protein contents but with a double value $(0.77$ vs. 0.34 for protein and fat percentage, respectively), but 18:0 and cis-9 C18:1 showed an opposite sign and greater values. The reason for this high positive correlation between cis-9 C16:1 and protein percentage is still unclear.

\section{CONCLUSIONS}

This study suggests the possibility of improving milk FA composition by genetic selection. Selection for fat and protein percentage may lead to increased C16:0 and to decreased trans-11 C18:1, cis-9, trans-11 C18:2. Indirect improvements are not expected on DI and MUFA using fat and protein percentages, but direct selection should be possible due to moderate to intermediate estimated heritability values. The implementation of cheap methods to determine milk FA composition is needed to improve future breeding objectives in dairy cattle populations.

\section{ACKNOWLEDGMENTS}

Research supported by the Italian Ministero dell'Università e della Ricerca Scientifica (COFIN 2003). The authors also thank to Marije B. Blok for her English suggestions.

\section{REFERENCES}

Bauman, D. E., B. A. Corl, L. H. Baumgard, and J. M. Griinari. 2001. Conjugated linoleic acid (CLA) and the dairy cow. Pages 221-250 in Recent Advances in Animal Nutrition 2001. P. C. Garnsworthy and J. Wiseman, ed. Nottingham University Press, Nottingham, UK.

Bauman, D. E., I. H. Mather, R. J. Wall, and A. L. Lock. 2006. Major advances associated with the biosynthesis of milk. J. Dairy Sci. 89:1235-1243.

Bernard, L., C. Leroux, and Y. Chilliard. 2006. Characterization and nutritional regulation of the main genes in the lactating mammary gland. Pages 295-326 in Ruminant Physiology. K. Sejrsen, T. Hvelplund, and M. O. Nielsen, ed. Wageningen Academic Publisher, Wageningen, the Netherlands.

Bobe, G., G. L. Lindberg, A. E. Freeman, and D. C. Beitz. 2007. Short communication: composition of milk protein and milk fatty acids is stable for cows differing in genetic merit for milk production. J. Dairy Sci. 90:3955-3960.

Bobe, G., J. A. Minick Bormann, G. L. Lindberg, A. E. Freeman, and D. C. Beitz. 2008. Short communication: estimates of genetic 
variation of milk fatty acids in US Holstein cows. J. Dairy Sci. 91:1209-1213.

Christie, W. W. 1982. A simple procedure of rapid transmethylation of glycerolipids and cholesteryl esters. J. Lipid Res. 23:1072-1075.

Corl, B. A., L. H. Baumgard, D. A. Dwyer, J. M. Griinari, B. S. Phillips, and D. E. Bauman. 2001. The role of $\Delta^{9}$-desaturase in the production of cis-9, trans-11 CLA. J. Nutr. Biochem. 12:622630 .

Edwards, R. A., J. W. B. King, and I. M. Yousef. 1973. A note on the genetic variation in the fatty acid composition of cow milk. Anim. Prod. 16:307-310.

Groeneveld, E. 1998. REML VCE A Multivariate Multi Model Restricted Maximum Likelihood (Co)variance Component Estimation Package. Version 4 User's Guide. Inst. Anim. Husbandry Anim. Behav., Fed. Agr. Res. Ctr., Neustadt, Germany.

Hansen, H. O., and J. Knudsen. 1987. Effects of exogenous long chain fatty acids on individual fatty acid synthesis by dispersed ruminant mammary gland cells. J. Dairy Sci. 70:1350-1354.

Harfoot, C. G., and G. P. Hazlewood. 1988. Lipid metabolism in the rumen. Pages 285-322 in The Rumen Microbial Ecosystem. P. N. Hobson, ed. Elsevier Applied Science Publishers, London, UK.

Jenkins, T. C., and M. A. McGuire. 2006. Major advances in nutrition: Impact on milk composition. J. Dairy Sci. 89:1302-1310.

Karijord, Ø., N. Standal, and O. Syrstad. 1982. Sources of variation in composition of milk fat. Z. Tierzüchtg. Züchtgsbiol. 99:81-93.

Kay, J. K., W. J. Weber, C. E. Moore, D. E. Bauman, L. B. Hansen, H. Chester-Jones, B. A. Crooker, and L. H. Baumgard. 2005. Effects of week of lactation and genetic selection for milk yield on milk fatty acid composition in Holstein cows. J. Dairy Sci. 88:3886-3893

Keys, A., J. T. Anderson, and F. Grande. 1965. Serum cholesterol response to change in the diet IV. Particular saturated fatty acids in the diet. Metabolism 14:776-786.

Kinsella, J. E., and M. Gross. 1973. Palmitic acid and initiation of mammary glyceride synthesis via phosphatidic acid. Biochim. Biophys. Acta 316:109-113.

Korver, S. 1988. Genetic aspects of feed intake and feed efficiency in dairy cattle: A review. Livest. Prod. Sci. 20:1-13.

Lock, A. L., and P. C. Garnsworthy. 2003. Seasonal variation in milk conjugated linoleic acid and $\Delta^{9}$ desaturase activity in dairy cows. Livest. Prod. Sci. 79:47-59.

Malau-Aduli, A. E. O., B. D. Siebert, C. D. K. Bottema, and W. S. Pitchford. 1997. A comparison of the fatty acids composition of triacylglycerols in adipose tissue from Limousine and Jersey cattle. Aust. J. Agric. Res. 48:715-722.

Mele, M., G. Conte, B. Castiglioni, S. Chessa, N. P. P. Macciotta, A. Serra, A. Buccioni, G. Pagnacco, and P. Secchiari. 2007. StearoylCoA desaturase gene polymorphism and milk fatty acid composition in Italian Friesian Cows. J. Dairy Sci. 90:4458-4465.

Ntambi, J. M. 1999. Regulation of stearoyl-CoA desaturase by polyunsaturated fatty acids and cholesterol. J. Lipid Res. 40:1549-1558.

Ntambi, J. M., and M. Miyazaki. 2004. Regulation of stearoyl-CoA desaturases and role in metabolism. Prog. Lipid Res. 43:91-104.

O'Donnell, J. A. 1993. Future of milk fat modification by production or processing integration of nutrition, food science, and animal science. J. Dairy Sci. 76:1797-1801.

Palmquist, D. L., A. D. Beaulieu, and D. M. Barbano. 1993. Feed and animal factors influencing milk fat composition. J. Dairy Sci. 76:1753-1771.
Palmquist, D. L., N. St-Pierre, and K. E. McClure. 2004. Tissue fatty acid profiles can be used to quantify endogenous rumenic acid synthesis in lambs. J. Nutr. 134:2407-2414.

Pariza, M. W. 1999. The biological activities of conjugated linoleic acid. Pages 12-20 in Advances in Conjugated Linoleic Acid Research, Vol. I. M. P. Yurawecz, M. M. Mossoba, J. K. G. Kramer, M. W. Pariza, and G. J. Nelson, ed. AOCS Press, Champaign, IL.

Renner, E., and U. Kosmack. 1974a. Genetische Aspekte zur Fettsaurenzusammensetzung des Milchfettes. 2. Fettsaurenmuster der Milch von Nachkommenpopulationen. Zuchtungskunde $46: 217-226$.

Renner, E., and U. Kosmack. 1974b. Genetische Aspekte zur Fettsäurenzusammensetzung des Milchfettes. 3. Genetic Korrelationen zum Fettgehalt und zur Fettleistung. Züchtungskunde 46:257-264.

Royal, M. D., and P. C. Garnsworthy. 2005. Estimation of genetic variation in $\Delta^{9}$-desaturase enzyme activity in dairy cows. Page 52 in Proc. Br. Soc. Anim. Sci., York, UK. Br. Soc. Anim. Sci. Penicuik, UK.

SAS. 2004. SAS User's Guide: Statistics, Version 9.1 ed. SAS Institute Inc., Cary, NC.

Schennink, A.. J. M. Heck, H. Bovenhuis, M. H. P. W. Visker, H. J. F. van Valenberg, and J. A. M. van Arendonk. 2008. Milk fatty acid unsaturation: genetic parameters and effects of stearoyl-CoA desaturase (SCD1) and acyl CoA: diacylglycerol acyltransferase 1 (DGAT1). J. Dairy Sci. 91:2135-2143.

Secchiari, P. M. Antongiovanni, M. Mele, A. Serra, A. Buccioni, G. Ferruzzi, F. Paoletti, and F. Petacchi. 2003a. Effect of kind of dietary fat on quality of milk fat from Italian Friesian cows. Livest. Prod. Sci. 83:43-52.

Secchiari, P., M. Mele, A. Serra, A. Buccioni, F. Paoletti, and M. Antongiovanni. 2003b. Effect of breed, parity and stage of lactation on milk conjugated linoleic acid content in Italian Friesian and Reggiana cows. Ital. J. Anim. Sci. 2(Suppl. 1):269-271.

Sol Morales, M., D. L. Palmquist, and W. P. Weiss. 2000. Effect of fat source and copper on unsaturation of blood and milk triacylglycerol fatty acids in Holstein and Jersey cows. J. Dairy Sci. 83:21052111.

Soyeurt, H., P. Dardenne, A. Gillon, C. Crocquet, S. Vanderick, P. Mayeres, C. Bertozzi, and N. Gengler. 2006. Variation in fatty acid contents of milk and fat within and across breeds. J. Dairy Sci. 89:4858-4865

Soyeurt, H., A. Gillon, S. Vanderick, P. Mayeres, C. Bertozzi, and N. Gengler. 2007. Estimation of heritability and genetic correlations for the major fatty acids in bovine milk. J. Dairy Sci. 90:44354442.

Stoop, W. M., J. A. M. van Arendonk, J. M. L. Heck, H. J. F. van Valenberg, and H. Bovenhuis. 2008. Genetic parameters for major milk fatty acids and milk production traits of Dutch HolsteinFriesians. J. Dairy Sci. 91:385-394.

White, S. L., J. A. Bertrand, M. R. Wade, S. P. Washburn, J. T. Jr Green, and T. C. Jenkins. 2001. Comparison of fatty acid content of milk from Jersey and Holstein cows consuming pasture or total mixed ration. J. Dairy Sci. 84:2295-2301.

Wolff, R. L., and C. C. Bayard. 1995. Improvement in the resolution of individual trans 18-1 isomers by capillary gas liquid chromatography: use of a $100 \mathrm{~m}$ CP Sil-88 column. J. Am. Oil Chem. Soc. 72:1197-1201. 